\title{
Z historie Ústavu soudního inženýrství Vysokého učení technického v Brně - II
}

\author{
From the History of the Institute of Forensic Engineering, \\ Brno University of Technology - part II
}

Albert Bradáć ${ }^{*}$, emeritní profesor

V předchozím příspěvku jsme se zabývali počátečním obdobím vzniku ústavu přibližně do roku 1969, včetně stručné znalecké analýzy některých nehod. Dnes navážeme podrobnější systémovou znaleckou analýzou jedné z největších železničních nehod, která se stala před padesáti lety, $\mathrm{v}$ ranních hodinách dne 11. prosince 1970, na kamenném viaduktu u stanice Řikonín na dvoukolejné elektrifikované trati Brno - Žd'ár nad Sázavou. Do nákladního vlaku ESn 4094 směřujícího do Brna, jenž v dané chvíli stál před Řikonínem a jeho konec byl právě na viaduktu, najela zezadu lokomotiva ELv 900, omylem hláskařky v Níhově vpuštěná do obsazeného oddílu. Nárazem bylo mj. čelo jednoho z vagonů nákladního vlaku vysunuto nahoru a doleva, do profilu protisměrné koleje. Do něj najela lokomotiva mezinárodního expresu EEx 57 Pannonia, jenž přijel po souběžné koleji z protisměru. Po postupně rostoucí demolici lokomotivy došlo k odtržení skříně prvního vagonu expresu z podvozku a její demolici, další vůz byl shozen na svah pod viaduktem, třetí zůstal jen zázrakem stát nakloněný na bok. Př́i katastrofẽ tehdy zahynulo 31 lidí, z toho 30 polských železničářů v demolovaném prvním, polském, spacím voze.

Podrobný popis nehody i s fotografiemi je dostupný na webu (pod hesly Řikonín, Řikonín 1970, Řikonín nehoda apod.). Nedočteme se tam však, že podrobnou znaleckou analýzu vzniku a průběhu nehody prováděl na žádost vyšetřovatele právě Ústav soudního inženýrství VUT v Brně pod vedením pana Ing. Jiřího

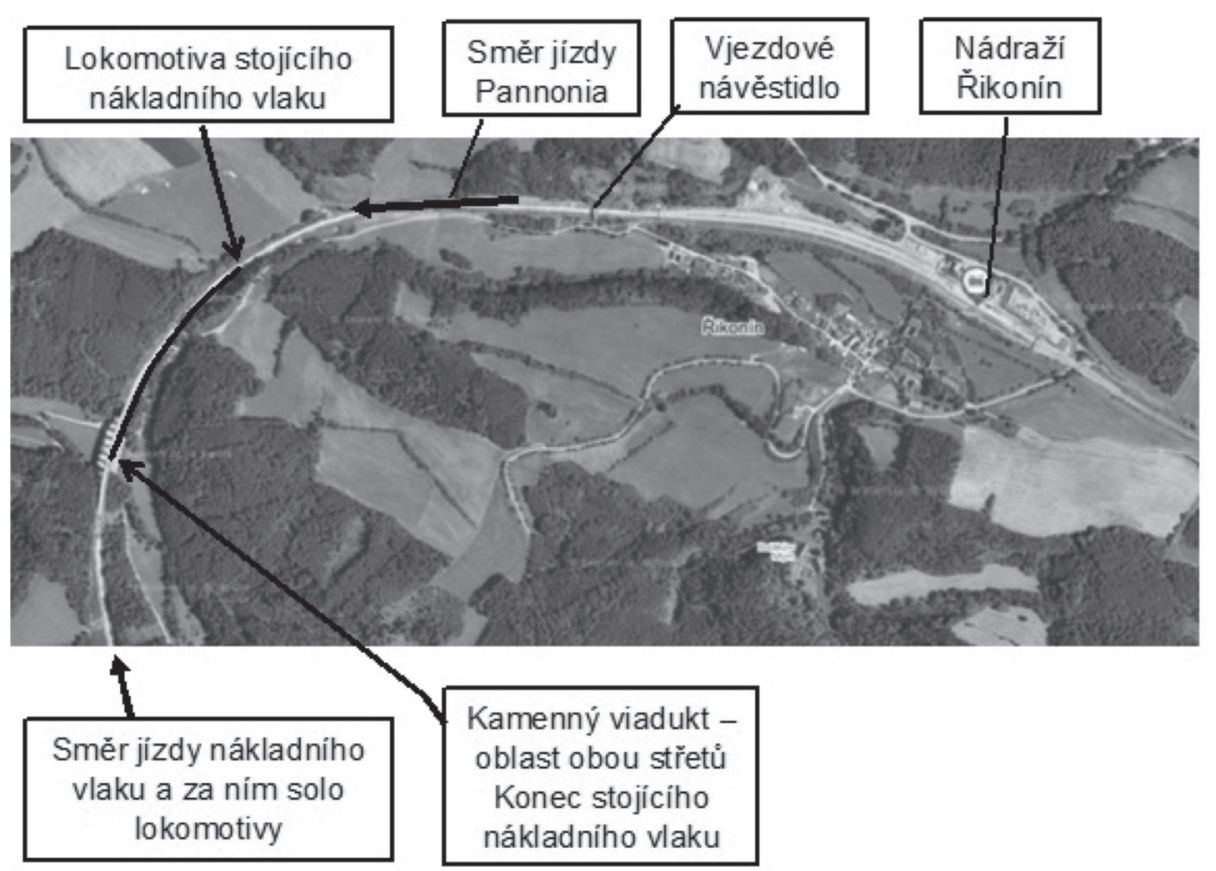

Obr. 1 Situace místa železniční nehody u Řikonína 11. 12. 1970. Podklad: mapy.cz (2020).

Fig. 1 Situation at the location of rail accident near Řikonín Decembre 11, 1970. Background: mapy.cz. 


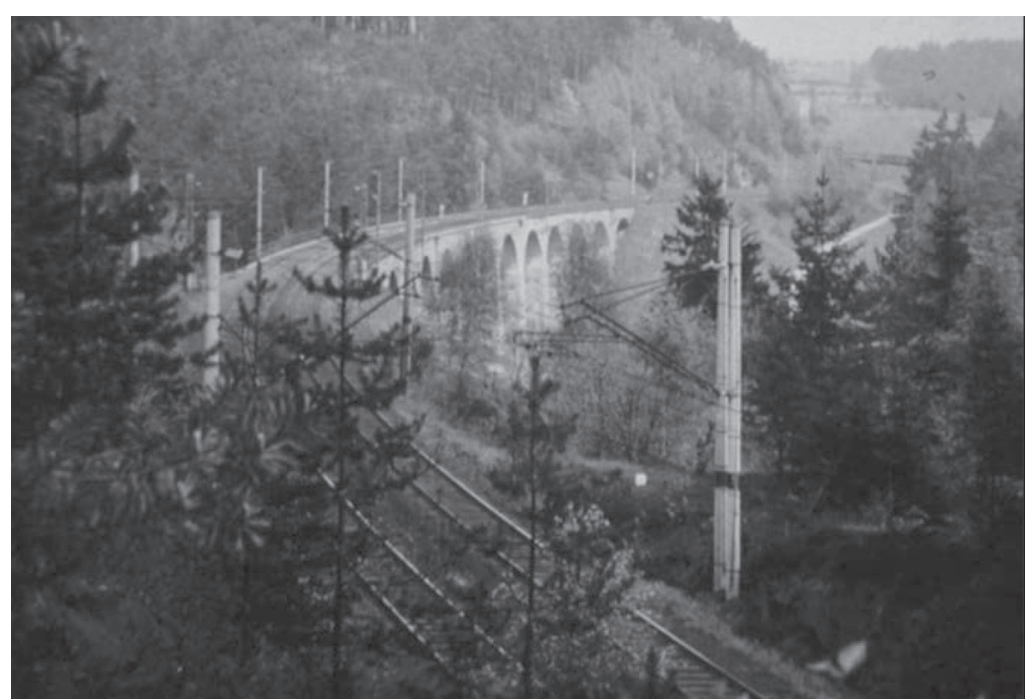

Obr. 2 Misto katastrofy (snímek z roku 1971): kamenný viadukt mezi Níhovem a Řikonínem na trati Žd'ár nad Sázavou - Brno. Pohled ve směru jizdy nákladního vlaku a solo lokomotivy, expres Pannonia přijel v protisměru od Řikonina.

Fig. 2 Place of the disaster (picture from 1971): a stone viaduct between Nihov and Řikonín on the Žd'ár nad Sázavou - Brno line. Looking in the direction of the freight train and solo locomotive, the Pannonia Express arrived in the opposite direction from Řikonín.

Smrčka, jmenovitě pánové prof. Ing. dr. Vladimír Enenkl, prof. Ing. Vladimír Zeman, doc. Ing. dr. techn. Jaroslav Kovařík a autor tohoto pojednání. (Pozn.: bylo to ještě před nástupem počítačů, textových editorů resp. tabulkových procesorů).

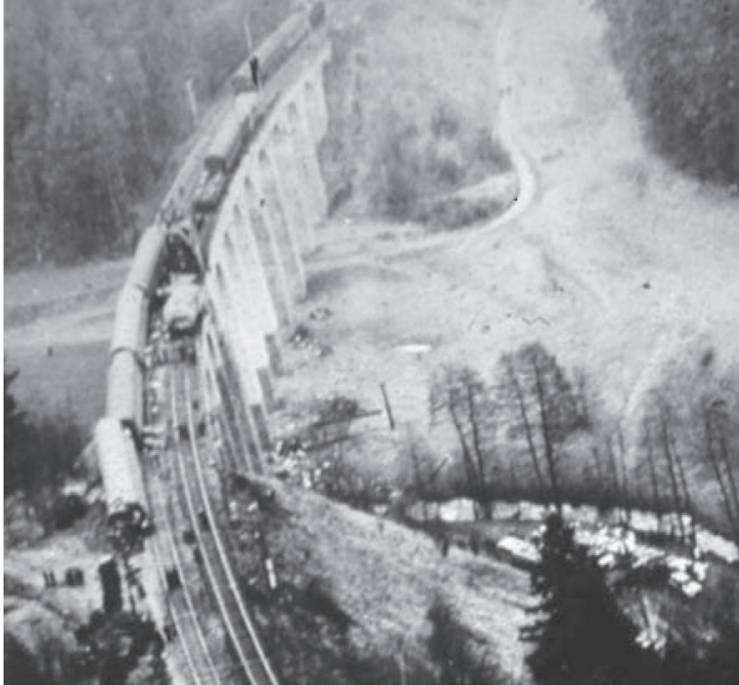

Obr. 3 Stav po nehodè. Na levé koleji třetí a dalši vozy expresu Pannonia, vlevo dole na svahu druhý vioz a trosky skřině prvniho; odtržená lokomotiva s podvozkem prvniho vagonu je dále dole mimo záběr. Vpravo dole pod mostem plošinové vozy nákladního vlaku.

Fig. 3 Condition after the accident. On the left track the third and other Pannonia express cars, at the bottom left on the slope the second car and the wreckage of the first box; the detached locomotive with the chassis of the first wagon is further out of engagement at the bottom. At the bottom right under the bridge, platform cars of a freight train.

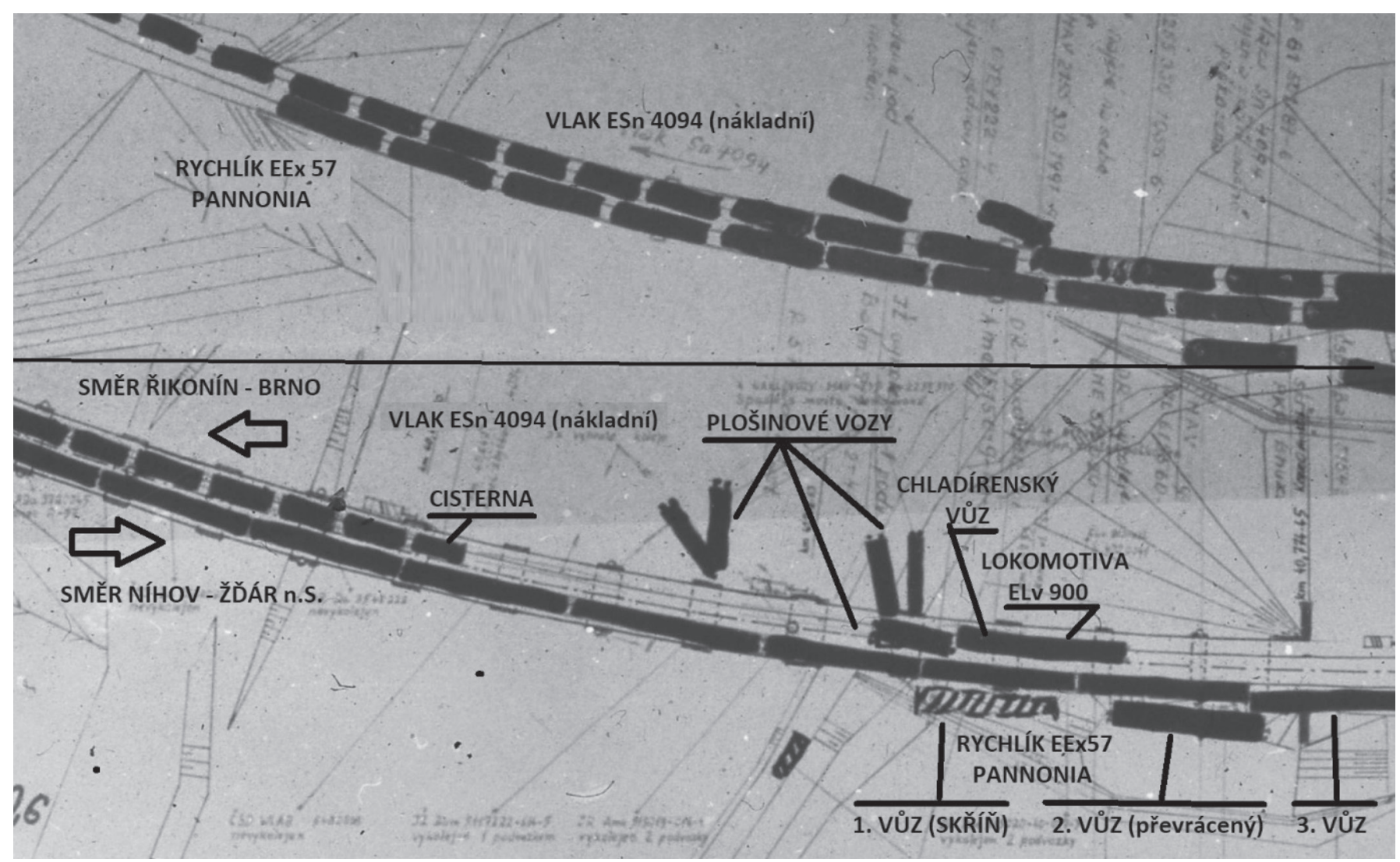

Obr. 4 Původní a upřesněný plánek situace po nehodě. Podklad: Geodetická služba ČSD.

Fig. 4 Original and detailed plan of the situation after the accident. Background: Geodetic service of CSD. 


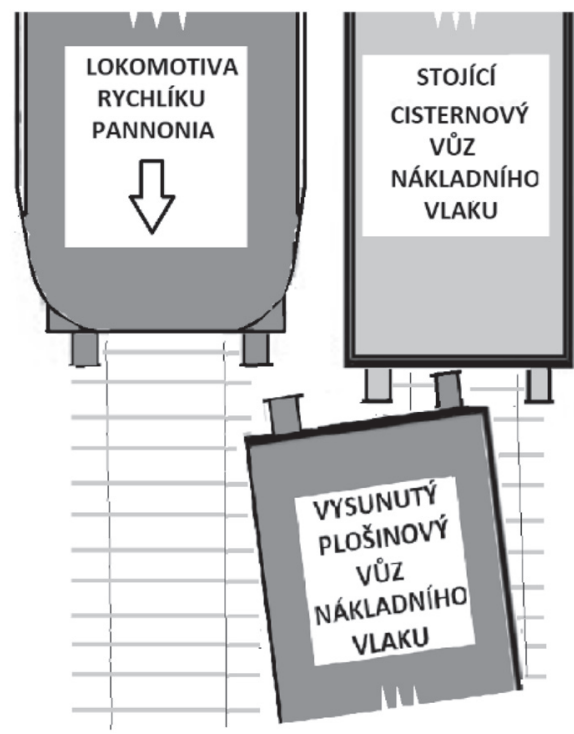

Obr. 5 Schematický půdorys začátku druhého střetu (jedoucí lokomotiva rychliku Pannonia do vysuntého plošinového vozu nákladního vlaku); bez měřitka.

Fig. 5 Schematic plan view of the beginning of the second collision (moving locomotive of the Pannonia express train to the platform of a freight train); without scale.

Nejprve bylo třeba shromáždit podklady - plány tratě, nákresy místa nehody, fotografie, skutečnosti z výpovědí svědků a přeživších účastníků nehody, a pak ověřit jejich technickou přijatelnost. Důležité bylo upřesnit zejména postavení jednotlivých vozů po nehodě (obr. 4).

Druhou fází byla analýza možnosti odvrácení prvního střetu strojvedoucím solo lokomotivy po spatření konce nákladního vlaku. Ve stejné ranní době byl proveden v daném místě, jež je v oblouku a trat' vybíhá na most ze skalního zářezu (obr. 6), vyšetřovací pokus dohlednosti z obdobné lokomotivy na stejný chladírenský vůz, jaký byl na konci nákladního vlaku. Jako jediná solo lokomotiva měla funkční tachograf, z jehož záznamu bylo zjištěno, že jela povolenou rychlostí a že strojvedoucí reagoval okamžitě po spatření konce vlaku nouzovým brzděním (obr. 7); zbývající vzdálenost však neumožňovala zastavení na dohled, jen snížení rychlosti.

Za zmínku jistě stojí i nečekaný výsledek tohoto vyšetřovacího pokusu. Strojvedoucí, jenž tlačil chladírenský vagon z Řikonína do místa pokusu, jel vlastně po koleji pro protisměrnou jízdu, měl proto směrem k Řikonínu vzadu rozsvícena červená koncová světla, po zastavení je nepřepnul za bílá. V době pokusu ovšem po druhé koleji přijížděl podle jízdního řádu opět expres Pannonia. Jeho strojvedoucí, když uviděl v místě předešlé havárie červená světla na čele lokomotivy na sousední koleji a plno lidí kolem trati, reagoval okamžitě nouzovým brzděním; vlak následně zastavil ještě před místem druhého střetu (jeho strojvedoucí vystoupil zcela bledý). Výsledek ovšem pro vyšetřovatele dokumentoval, že kdyby býval po prvním střetu strojvedoucí nákladního vlaku reagoval po zjištění možné poruchy v souladu s předpisy některou z předepsaných návěstí pro protijedoucí vlak, ke druhému střetu by bývalo nedošlo.

Třetí fází práce ústavu bylo odvodit mechanismus druhého střetu, nárazu expresu Pannonia; využita byla analýza korespondence poškození vozidel. Složení konce nákladního vlaku bylo následující:

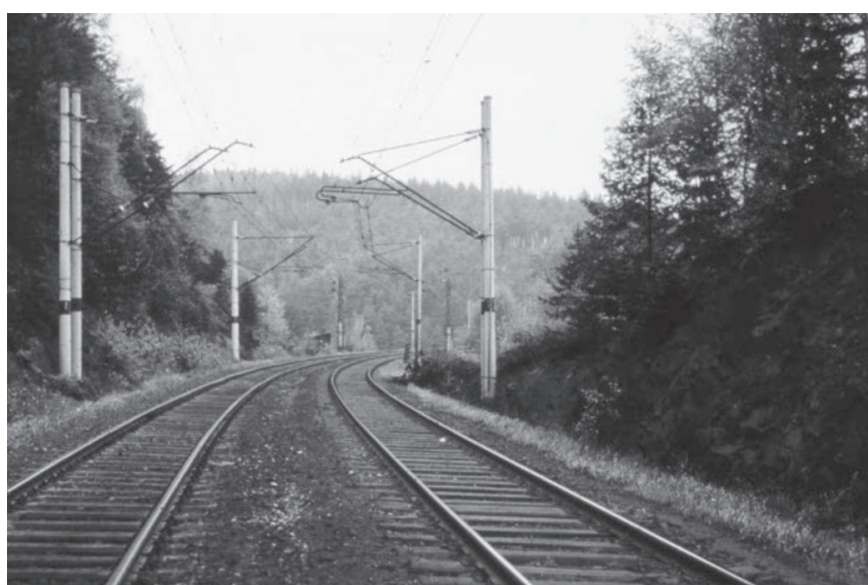

Obr. 6 Př́jezd ze zářezu od Níhova na předmětný viadukt-směr jizdy nákladniho vlaku a následně solo lokomotivy ELv 900 (snímek z roku 1971).

Fig. 6 Arrival from the notch from Nihov to the viaduct - the direction of the freight train and then the solo locomotive ELv 900 (picture from 1971).

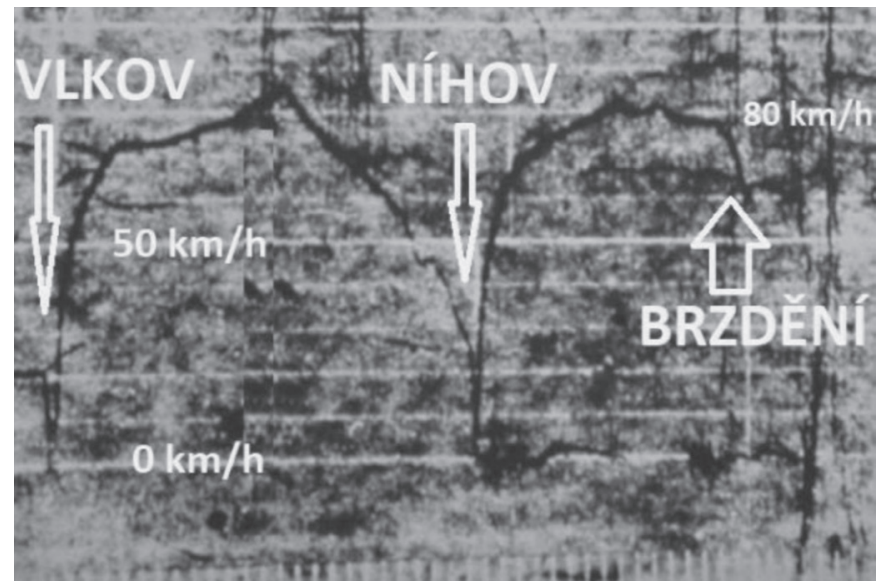

Obr. 7 Záznam tachografu ELv 900 (solo lokomotiva, jež narazila zezadu na nákladní vlak ESn 4094; fotografie záznamu na voskovaném papíru).

Fig. 7 Record of the tachograph ELv 900 (solo locomotive that hit the freight train ESn 4094 from behind; photograph of the record on waxed paper).

- poslední vůz byl chladírenský, naložený sudy s pivem,

- před ním bylo 6 prázdných plošinových vozů s nízkými bočnicemi, $z$ toho po druhém střetu:

- 2 byly těsně před chladírenským vozem, nasunuty na sobě,

- $4(2+2)$ skončily pod viaduktem, na viaduktu byla po nich v nákladním vlaku mezera a posunutá kolej,

- před mezerou byl zbytek vlaku, posledním byl naložený cisternový vůz, zezadu poškozený.

Z fotografií deformace cisternového vozu (viz obr. 9) bylo zjištěno, že v důsledku sil působících při prvním střetu na konec nákladního vlaku došlo k nasunutí čela plošinového vozu nahoru a doleva na čelo plného cisternového vozu. Pravý nárazník plošinového vozu se otiskl doprostřed čela cisterny, levý nárazník byl vysunut do protisměru. Do tohoto levého nárazníku narazila 


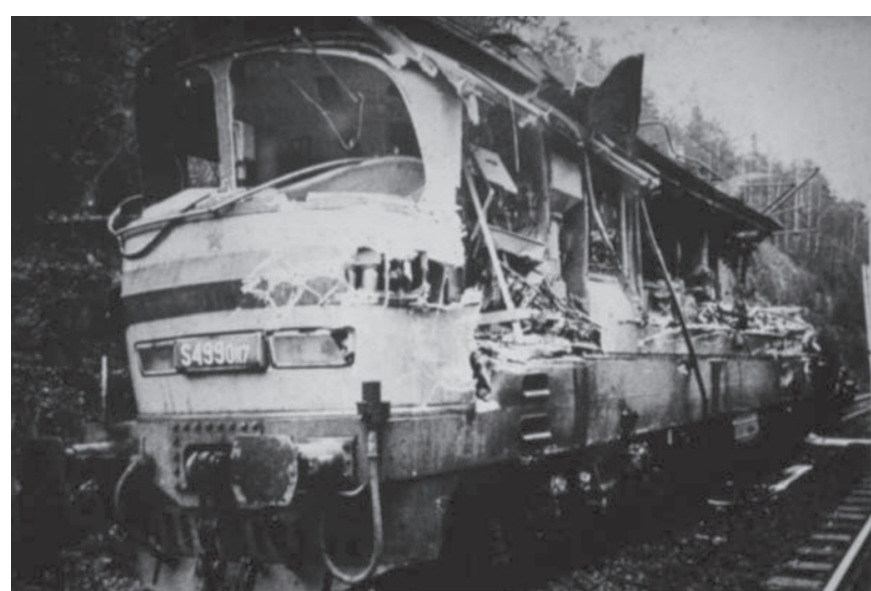

Obr. 8 Poškození lokomotivy expresu Pannonia, nejprve jen levým okrajem resp. nárazníkem vysunutého plošinového vozu.

Fig. 8 Damage of the Pannonia express locomotive, initially at the first by the left side resp. bumper of the extended platform truck.

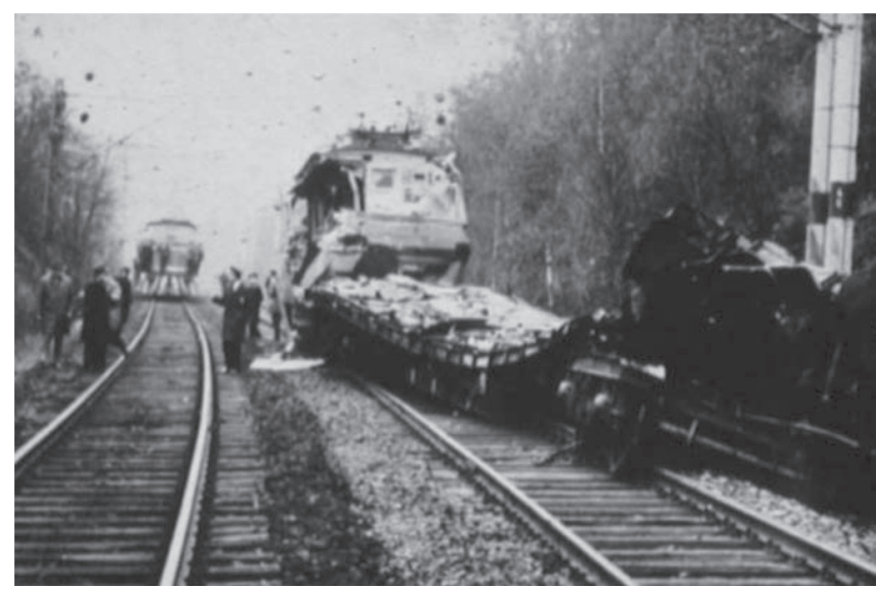

Obr. 10 Lokomotiva a podvozek spacího vozu expresu Pannonia po odtrženi skřinè.

Fig. 10 Locomotive and chassis of the Pannonia express sleeping carriage after the box has been torn off.

čelně levou stranou lokomotiva protijedoucího expresu Pannonia (pomocník strojvedoucího ještě stačil uskočit) - obr. 5, 8. Střet byl excentrický, střetová síla směřovala mimo těžiště, zejména u nákladního vagonu. Vzniklým momentem při rostoucím rameni působící síly došlo $\mathrm{k}$ levotočivé rotaci nákladního vozu kolem svislé osy; vůz postupně pronikal hlouběji do skříně lokomotivy, zadní plošinu již zdemoloval zcela (obr. 8 a 10), následně pak způsobil odtržení skříně prvního vagonu a její pád na svah pod mostem; podvozek prvního vozu pokračoval dále za lokomotivou (obr. 10). Působící silou reakce byla také vybočena kolej pod nákladním vlakem směrem vně z mostu.

V dalším byla zjišt'ována možnost odvrácení druhého střetu strojvedoucím protijedoucího EEx 57 Pannonia po spatření překážky - vysunutého čela nákladního vozu. Vyšetřovacím pokusem byla zjišt'ována dohlednost kolem obdobně sestaveného nákladního vlaku, stojícího v daném oblouku, na vysunuté čelo plošinového vozu za cisternou. Následně byl proveden výpočet možnosti reakce a zastavení; nebylo zjištěno, že by strojvedoucí nejednal okamžitě. Komplikací bylo, že nebyla známa okamžitá rychlost expresu

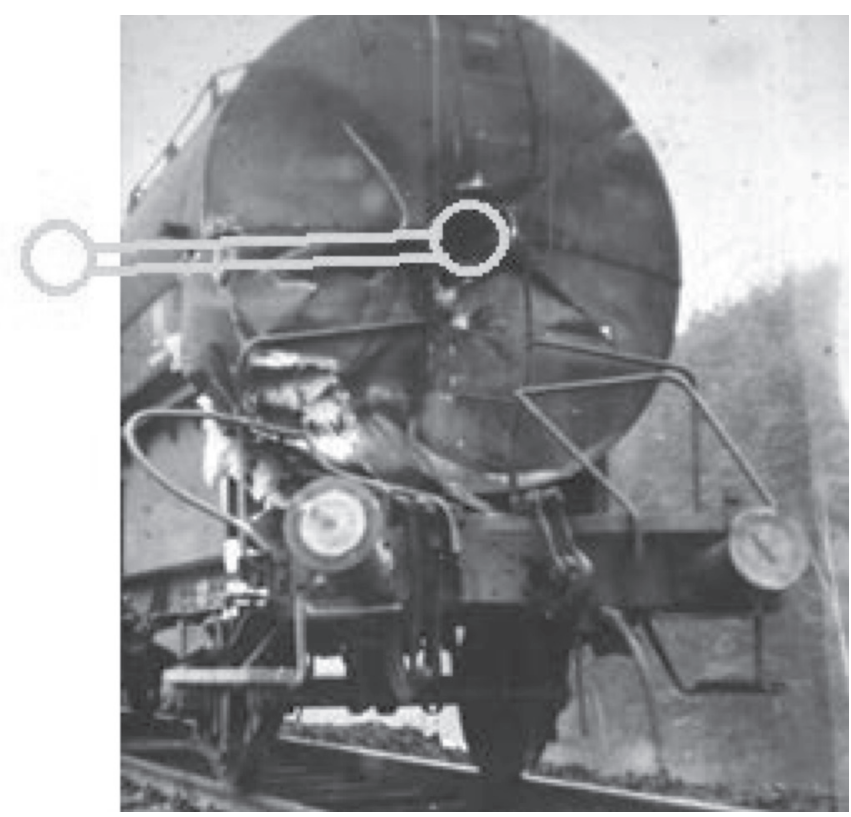

Obr. 9 Poškozeni čela cisterny nasunutím čela a pravého nárazníku plošinového vozu $v$ důsledku prvního střetu.

Fig. 9 Damage to the tank front by sliding the front and right bumper of the platform truck as a result of the first collision.

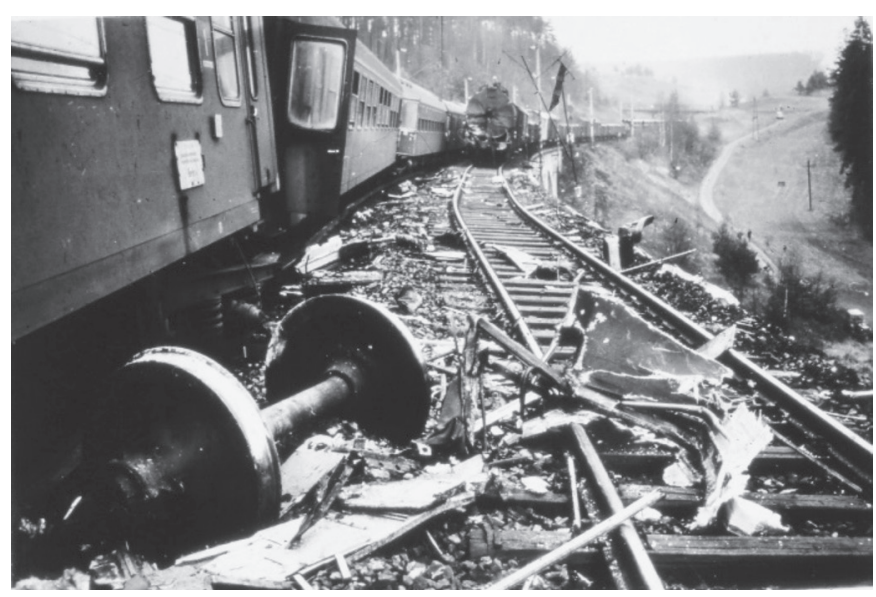

Obr. 11 Mezera po nákladnich vozech, cisternový vůz, vybočená kolej.

Fig. 11 The gap after the freigh railroad car, tank, deviated track.

Pannonia, poněvadž jeho tachograf (stejně jako u nákladního vlaku) údajně nebyl funkční; vycházelo se proto ze zaznamenaných dob průjezdu předchozími stanicemi a z toho vypočtených průměrných rychlostí (zejména zda vlak nepřekročil maximální předepsanou rychlost), následně pak bylo také porovnáno se zaznamenanou rychlostí dalších rychlíků v daném místě.

Následovala analýza možnosti odvrácení druhého střetu osádkou stojícího nákladního vlaku. $\mathrm{K}$ tomu bylo zapotrebí zjištění času mezi prvním nárazem a průjezdem protijedoucího expresu EEx 57, aby byla zjištěna časová možnost strojvedoucího nákladního vlaku v souladu s předpisy předpokládat problémy i na sousední koleji a dát návěst „Stůj, zastavte všemi prostředky!“ (červená světla na čele lokomotivy pro varování protijedoucího vlaku, výbušné náložky - „třaskavky“ - na koleje, kroužení rukou resp. houkání 


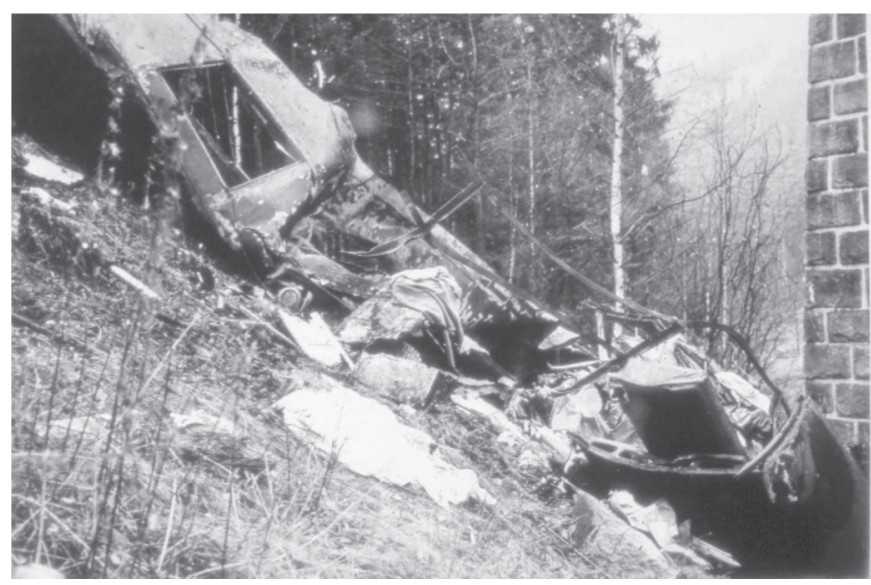

Obr. 12 Trosky odtržené skřině prvního vozu rychliku Pannonia. Fig. 12 The wreckage of the torn-off body of the first Pannonia express railroad car.

protijedoucímu vlaku $\mathrm{v}$ ústrety). V této souvislosti byl proveden další vyšetřovací pokus s cílem zjistit, zda by při návěsti dané strojvedoucím nákladního vlaku houkačkou lokomotivy nedošlo k přkrytí jejího zvuku hlukem v kabině expresu; v akustice je toto známo pod pojmem maskování a dochází k němu zejména, pokud jsou oba zvuky o přibližně stejné frekvenci. ${ }^{1)}$ Byla provedena zkušební jízda a houkání v protisměru a bylo zjištěno, že frekvence houkaček elektrické lokomotivy na střídavý proud není zrovna optimální.

Z výpovědí osádky nákladního vlaku vyplynulo, že po rozběhnutí kompresorů jejich vlaku po prvním nárazu dal strojvedoucí pokyn pomocníkovi, ten se nejprve přemístil na druhou plošinu, tam vzal náhradní hadici, slezl dolů, šel kolem několika vozů, pro lepší pohyb po trati přelezl na druhou stranu vlaku a potom kolem projel expres. Jeho výpověd' nebylo možno technicky ověřit, posouzení věrohodnosti zůstalo na vyšetřovateli (viz též pozn. ${ }^{3)}$ ).

Následně pak byla provedena časová analýza průběhu činnosti jednotlivých účastníků - prvků nehodového systému:

- hláskařka na zastávce Níhov (žena z domácnosti, jejíž to byl první den ve službě po měsíčním školeni) - vpuštění lokomotivy do obsazeného oddílu, po zjištění chyby dva telefonáty výpravčímu do Řikonína;

- spěšný nákladní vlak ESn 4094, jenž původně jel směrem do Tišnova, ale tam bylo plno a tak měl být neplánovaně zastaven ve stanici Řikonín, což znamenalo nejprve jej po upozornění předvěstí (asi $700 \mathrm{~m}$ před návěstidlem) zastavit před stanicí a následně vpustit; na trati bylo přitom jen mechanické zabezpečovací zařízení2). Vlak projel zastávku Níhov a zastavil $300 \mathrm{~m}$ před vjezdovým návěstidlem stanice Řikonín, takže na něj ze stanice nebylo vidět, aby mohl být vpuštěn; obsazen byl strojvůdcem a pomocníkem ${ }^{3)}$. Po nárazu lokomotivy do konce nákladního vlaku se přerušilo brzdové potrubí a kompresory

\footnotetext{
1) Blíže k maskování v akustice viz např. http://fyzika.jreichl.com/main.article/ view/1179-maskovani-zvuku.

2) Údajně již bylo na trati připraveno $\mathrm{k}$ instalaci zabezpečovací zařízení elektrické, ale po vzniku federace bylo předisponováno na jinou trat' na Slovensku.

3) Neprokázalo se, že tak daleko před návěstidlem zastavili účelově, když bylo před Vánoci a v místě zastavění rostly jehličnaté stromky; při dodatečném ohledání bylo zjištěno, že už tam žádné nejsou, jen pařízky.
}

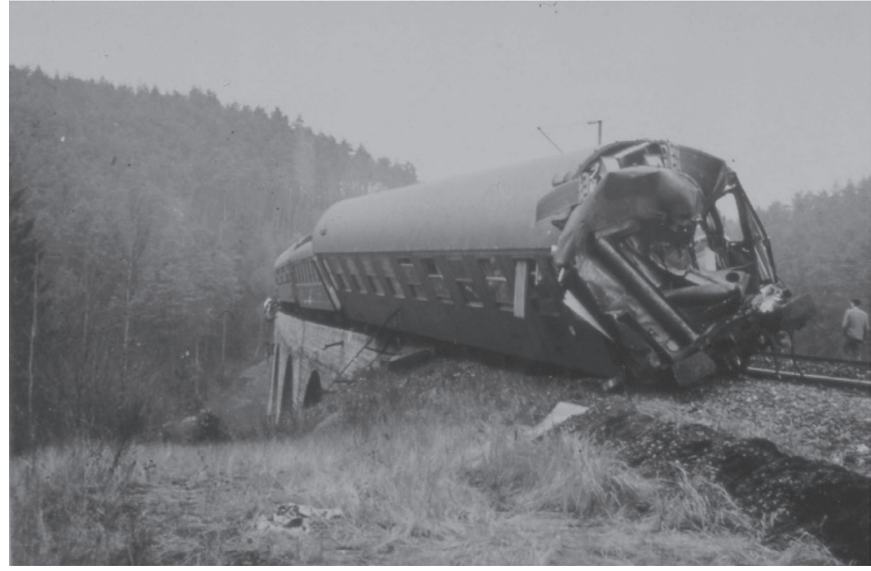

Obr. 13 Třetí vioz rychliku Pannonia.

Fig. 13 The third Pannonia express railroad car.

je začaly rychle doplňovat; strojvůdce na jejich zrychlenou činnost reagoval vysláním pomocníka dozadu zjistit poruchu resp. provést opravu potrubí, v rozporu s předpisy však nerozsvítil červená světla pro varování protijedoucího vlaku ani nedal jiným zpo̊sobem návěst „Stůj, zastavte všemi prostředky";

- lokomotiva ELv 900, jež tlačila jiný nákladní vlak z BrnaMaloměřic a následně se vracela z Vlkova zpět. V Níhově ji na žádost trat'mistra, který zaspal a potřeboval se dostat do práce, zastavila hláskařka. Poté, co trat'mistr nastoupil, dala lokomotivě mechanické návěstidlo (,semafor“) do polohy „volno“, aniž si uvědomila, že ještě nemá odhlášku od výpravčího z Řikonína, že tam předchozí nákladní vlak dojel ${ }^{4)}$. Tato lokomotiva pak na viaduktu narazila do posledního (chladírenského) vozu, jenž pak narazil do dalších ${ }^{5}$;

- expres EEx 57 Pannonia (resp. jeho přední část se strojvedoucím a pomocníkem); časy, kdy projel BrnoKrálovo Pole, Tišnov, Řikonín (postupně kolem signalisty na vjezdu do stanice, výpravčího, signalisty na odjezdu) a čas nárazu;

- výpravčí v Řikoníně, jehož hláskařka z Níhova nejprve po zjištění, že nemá zapsánu odhlášku za nákladním vlakem, o tuto odhlášku požádala, na což výpravčí reagoval krátkým sdělením, že vlak ještě nepřijel, a položil telefon. Po druhém telefonátu hláskařky a sdělení, že tam vpustila lokomotivu, dal signalistovi pokyn vpustit nákladní vlak do stanice i když jej tento neviděl, a šel na nástupiště, že nákladní vlak zastaví osobně. Bohužel ale přitom opomenul zastavit z druhé strany přijíždějící expres Pannonia na druhé koleji;

- rozvodna Čebín, z níž je elektrifikovaná trat' napájena. Zde zaznamenali a zapsali výpadek, způsobený zřjejmě zkratem při prvním nárazu. Po předepsané minutě prodlevy napájení opět zapnuli, to vydrželo jen další dvě minuty a pak již zapnutí nebylo možné.

4) Pan inženýr Smrček v nadsázce říkal: „Vlastně za to všechno mohl špatně nastavený budík".

5) Chladírenský vůz byl naložen sudy s plzeňským pivem, jež se pak válely po celém místě katastrofy; údajně snad jel bez dokladů. 


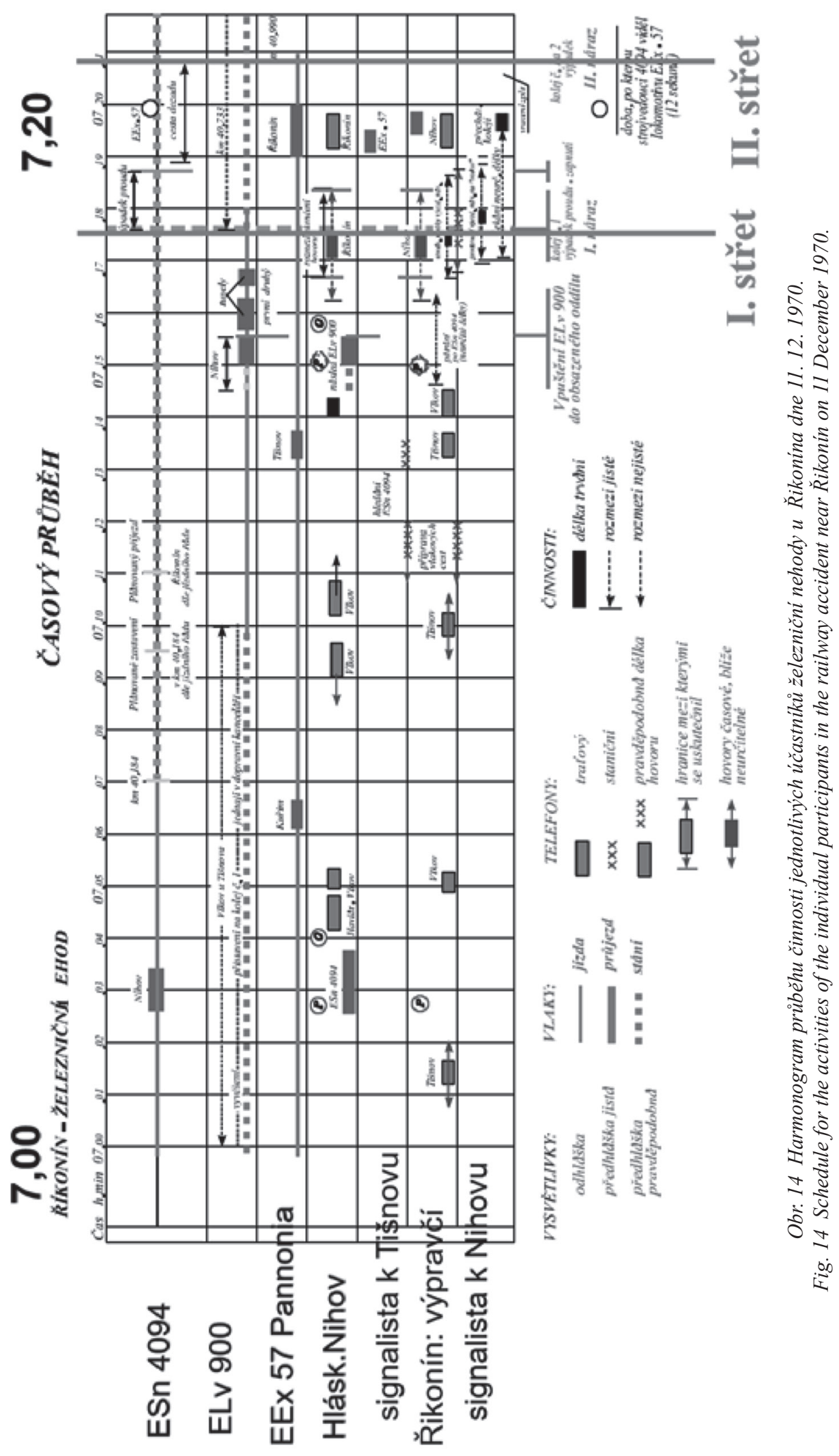




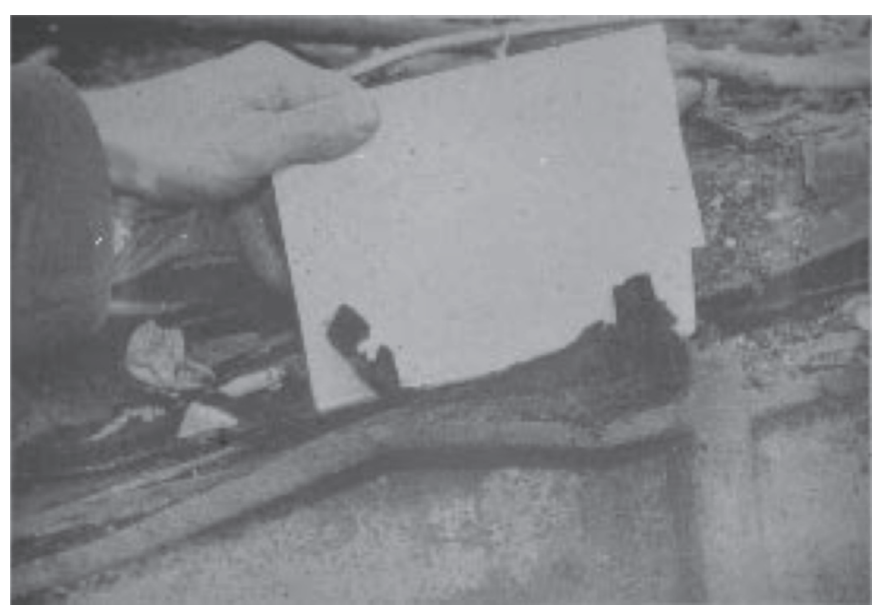

Obr. 15 Ukázka koroze skřině prvního vozu expresu Pannonia $v$ mistě uchyceni k podvozku.

Fig. 15 Demonstration of corrosion of the body of the first Pannonia express railroad car at the point of attachment to the chassis.

Časová analýza byla provedena za pomoci řádkového grafu harmonogramu (obr. 14). Pro jeho sestavení bylo třeba všechny děje uvést do jednotného času; za základ byly vzaty zaznamenané časy výpadků napájení v rozvodně Čebín, odpovídající prvnímu a druhému nárazu. Z harmonogramu pak byla zjištěna časová rozmezí, jež měli k dispozici jednotliví účastníci; například výpravčí ve stanici Řikonín měl od druhého telefonátu hláskařky z Níhova o vpuštění lokomotivy do obsazeného oddílu do průjezdu čela expresu Pannonia okolo něj k dispozici cca 45 vteřin (on se však soustředil na vpuštění nákladního vlaku do stanice).

Požadována byla také materiálová analýza rozpadlého lůžkového vozu, jenž byl polských železnic (otázka náhrady škody). Vůz byl původně vyřazen, polští železniční odboráři jej dali opět do provozu a jezdili s ním po Evropě. Podle zjištění jej ovšem zřejmě jen natřeli; při ohledání odstaveného podvozku bylo podle zbytků odtržené skřrině ověřeno, že skřriň byla značně zkorodovaná (obr. 15). Vůz v řádném stavu by se pravděpodobně nemohl rozpadnout nárazem plošinového vozu, odhodil by jej mimo profil, ale na druhou stranu nelze vyloučit ani opačný efekt, že by i více vozů spadlo z viaduktu...

Ještě jedna zajímavost: zpomalení expresu Pannonia během druhého střetu zřejmě nebylo př́liš veliké; jeho vlakvedoucí, jenž byl v té době přibližně uprostřed vlaku, si poznamenal: „7:20 zastavení u Řikonína“ a čekal, až pojedou dále.

Bez zajímavosti nejsou okolnosti, za nichž ústav posudek zpracovával. Bylo to období tzv. normalizace po Pražském jaru a následné okupaci vojsky Varšavské smlouvy v srpnu 1968.
$\mathrm{Na}$ univerzitě byl zrrizován celoškolský výbor Komunistické strany Československa a bylo třeba najít pro něj prostory. Bylo rozhodnuto, že Ústav soudního inženýrství, jenž sídlil ve dvou místnostech v tehdejší budově rektorátu na ulici Opletalově č. 6 , uvolní tyto prostory a přestěhuje se do větších prostor ve 4 . NP objektu Vlhká 25, v němž předtím byly koleje (původně bytový dům z 19. století); stěhování připadlo právě na období zpracovávání předmětného posudku. Objekt Vlhká 25 je zajímavý tím, že vedle něj do barvířské stoky padla za války bomba, vyhloubila kráter k základům, objekt se na jedné straně podmáčel, naklonil se a v této poloze byl sanován, takže podlahy jsou nepatrně ve sklonu (do spirály). Postupně se zde ústav rozšiřoval o další prostory kancelářské, velmi dobře vybavenou fotolaboratoř se skladem v podkroví a posluchárnu pro 30 posluchačů s projekční kabinou ve 3. nadzemním podlaží. (V objektu ústav setrval až do roku 1988, kdy škola objekt vyměnila za jiný, a ústav se přestěhoval do areálu Údolní 53.)

Vedoucím ústavu byl nadále pan inženýr Smrček ${ }^{6)}$; jako sekretářka dlouhou dobu působila paní Marie Pátková (roz. Marešová), knihovnu a rešeršní činnost vedl pan Ing. Jan Nesveda, fotolaboratoř vybudoval pan IngC. Jaroslav Jerman. Studijní oddělení vedla paní Jaroslava Fuxová a po jejím odchodu do důchodu paní Hana Franková (roz. Mazalová). Jako odborní pracovníci zde byli kromě pana inženýra Smrčka autor této vzpomínky, později pan Ing. Ladislav Glier (absolvent Fakulty strojní, odborník na IT) a (zpočátku na poloviční úvazek) pan Ing. Pavel Krejčír, odborný asistent Fakulty strojní, konstruktér motorových vozidel.

V době normalizace byla řada učitelů VUT vyloučena resp. vyškrtnuta $\mathrm{z}$ řad členů KSČ a bylo jim zapovězeno přednášet a zastávat řídící funkce; působili pak na škole v technických resp. vědeckých funkcích. Tyto odborníky pan Ing. Smrček, sám nestraník ${ }^{7)}$, zaměstnával při vypracovávání ústavních posudků; př́kladem mohou být např. pan prof. Ing. Vladimír Zeman (bývalý vedoucí katedry na Fakultě strojní), doc. Ing. Jiří Ošlejšek, CSc. (FAST) resp. prof. Ing. Dr. Ladislav Mejzlík, DrSc.

\footnotetext{
6) V roce 1979 byl vzhledem $k$ věku pana Ing. Jiř́iho Smrčka (73 let) jmenován ne jeho místo autor tohoto článku, jenž funkci zastával do roku 2012 (přesněji: jako nestraník byl pověřen zastupováním vedoucího ústavu, což vydrželo až do roku 1990).

Z období, kdy byl za války pět let vězněn, si pan inženýr Smrček přinesl další zajímavá úsloví, například:

- Zklamání je křivda, které se dopouštíme na druhém človéku, když po něm chceme vlastnosti, které on nikdy neměl; ale on za to nemůže.

- Zásadně nelžu, abych si nemusel pamatovat, co jsem kde komu říkal. 7) Jeho heslem v tomto směru bylo: „Jsme príslušníky strany technické, jež se řídí př́rodními zákony, které nepodléhají korozi ani jiným vlivům.““
}

\section{Správná citace:}

BRADÁČ , A. Z historie Ústavu soudního inženýrství Vysokého učení technického v Brně - II. Soudní inženýrství, 2020, 31(2), 53-59. DOI: http://dx.doi.org./10.13164/SI.2020.2.53. ISSN 1211-443X. 